\title{
Applying seismic stratigraphy analysis for assessing upper Oligocene stratigraphic traps in Southeastern Cuu Long Basin
}

\author{
Chuc Nguyen Dinh, Tu Nguyen Van, Hung Nguyen Quang \\ Cuong Bui Van, Thanh Truong Quoc, Xuan Tran Van
}

\begin{abstract}
As oil and gas production has been going on over a few decades, conventional plays such as pre-Tertiary fractured basement highs and Cenozoic structural traps become more and more exhausted, and the remaining targets of the same type do not have sufficient reserves for development and production. Exploration activities in Cuu Long basin, therefore, are shifting towards more complicating types of plays which are stratigraphic traps and combination traps. Several researches were conducted in southeastern marginal slope and indicated the possibility of stratigraphic pinch-out traps with insufficient petroleum system and low hydrocarbon potential. In spite of many researches, there are still difficulties in defining the distribution and in evaluating hydrocarbon potential of these traps, so seismic stratigraphy analysis in
\end{abstract}

Manuscript Received on August 7th, 2017. Manuscript Revised December 25th, 2017.

The authors thank Vietnam National Oil and Gas Group (PetroVietnam), PetroVietnam Exploration Production Corporation (PVEP) for the support and permission to publish this work. Contributing technical assistance and comments for this manuscript from PetroVietnam Domestic Exploration Production Operating Company (PVEP POC) and Ho Chi Minh City University of Technology - VNU-HCM are greatly acknowledged and appreciated. This research is funded by Ho Chi Minh City University of Technology - VNU-HCM, under grant number T-ĐCDK-2016-114.

Chuc Nguyen Dinh - PetroVietnam Domestic Exploration Production Operating Company Ltd (e-mail: ndchuc1977@gmail.com)

Tu Nguyen Van - PetroVietnam Domestic Exploration Production Operating Company Ltd.

Hung Nguyen Quang - PetroVietnam Domestic Exploration Production Operating Company Ltd.

Cuong Bui Van - PetroVietnam Exploration Production Corporation.

Thanh Truong Quoc - Department of Petroleum Geology, Faculty of Geology and Petroleum Engineering, Ho Chi Minh City University of Technology - VNU-HCM.

Xuan Tran Van - Department of Petroleum Geology, Faculty of Geology and Petroleum Engineering, Ho Chi Minh City University of Technology - VNU-HCM (e-mail: tvxuan@hcmut.edu.vn).

* Corresponding author: Email: ndchuc1977@gmail.com accompanied with interpretation of seismic attribute and well logs is very necessary to support this problem.

Seismic stratigraphic analysis on seismic sections, in agreement with seismic attributes' and log analysis' findings, show that the stratigraphic/combination traps in Oligocene $\mathrm{C}$ and $D$ were formed during lowstand system tract as sigmoid-oblique clinoforms downlapping onto underlying strata in distributary mouths/delta settings. The integration of seismic attribute analysis and well $\log$ interpretation has further defined the fan-shaped distribution of these traps. Thus, using various methods, the stratigraphic traps can be better revealed. Further studies, however, need to be carried out to fully evaluate hydrocarbon potential of these stratigraphic/ combination traps, and minimize risks in exploration drilling.

Index Terms-Stratigraphic trap, combination trap, facies change, lowstand system tract, seismic stratigraphy.

\section{INTRODUCTION}

$\mathrm{M}$ any petroleum activities that focus on traditional targets such as pre-Tertiary basement highs, Oligocene and Miocene structural traps have been carried out in the Cuu Long basin, the Cenozoic basin of the highest petroleum potential in Vietnam's shelf. Stratigraphic/ combination traps were considered secondary targets of previous exploration activities. Nevertheless, recent exploration/appraisal results at the basin's southeastern margin have discovered petroleum accumulations in Oligocene fan-shaped stratigraphic/combination traps [1]. These new discoveries show the necessity of additional attentions to these unconventional exploration targets.

The geology of the Southeastern margin of Cuu Long basin is complicated; therefore, it is difficult 
to determine whether such traps exists or not as well as to predict traps' distribution. Detailed analysis of seismic data shall provide convincing identification of various trap types for further evaluation of their hydrocarbon potential. This article discusses the characteristics of upper Oligocene stratigraphic traps, predictions of traps' distribution as well as identification of trapping mechanism to support for further exploration and appraisal strategy in the southeastern margin in particular and the whole basin in general.

\section{GEOLOGICAL SETTINGS}

Cuu Long basin was undergone by three main tectonic period: pre-rift (Late Jurassic to Paleocene), syn-rift (Late Eocene through Late Oligocene) and post-rift (early Miocene to Recent). Upper Oligocene sediments were deposited at late syn-rift stage of Cuu Long basin. At the end of Late Oligocene, local compressional activities pushed up deep basement blocks and basement highs which had been formed before along the major faults. It led to the reactivation of faults, erosion and pinching-out of Upper Oligocene sediments [2].

Upper Oligocene sediments are mainly shales interbedded with sandstones deposited in the lacustrine, flood plain or alluvial environments. The upper part of these strata (Oligocene C sediments) consists of more sandstones than the lower part (Oligocene D) (Figure 1). The reservoirs in upper Oligocene strata are mainly sandstones deposited in the flood plain or fluvial environments. The reservoirs have quite good quality with porosities varying from $12-24 \%$ and permeabilities being tens of miliDarcy [3]. Some of these reservoirs have been confirmed to be stratigraphic type of trap (Figure 2).

\section{METHODOLOGY}

The primary method of this study is seismic sequence stratigraphy analysis. The bases of seismic stratigraphy are based on analysis of patterns of seismic reflectors and analysis of sequences and system tracts from different authors using depositional sequence model as the main interpretation tool [4-7] (Figure 3). Seismic attributes analyses are based on applications of different attributes on the interpretation of depositional environment as well as the identification of internal patterns of stratigraphic units [7-11].

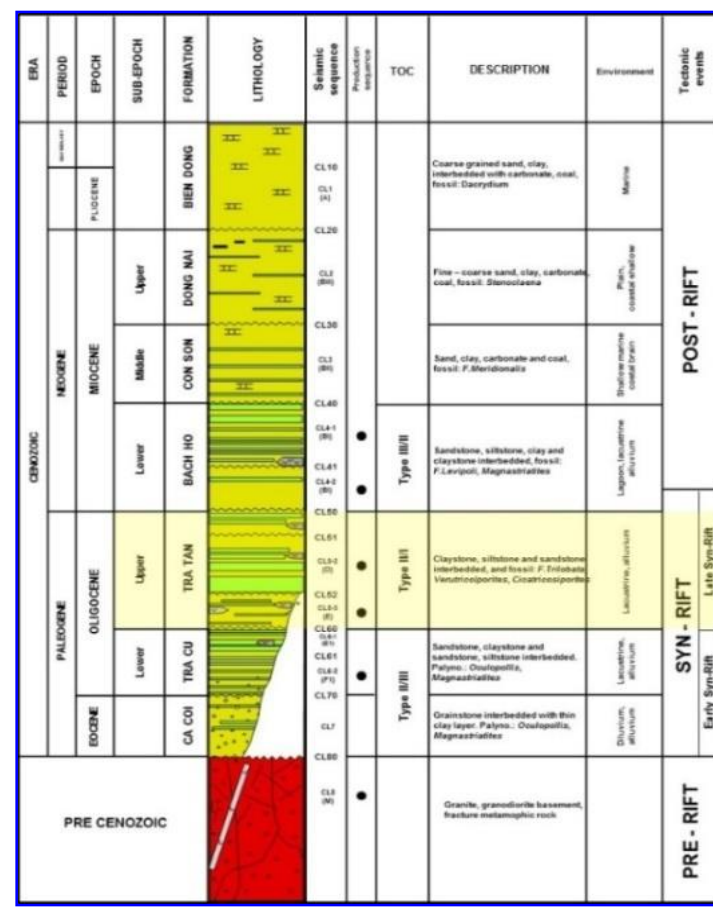

Figure 1. Stratigraphic column of southeast Cuu Long basin. The focused formation of this study is Upper Oligocene strata (highlighted in yellow) that deposited during the Late Syn-rift phase of Cuu Long basin

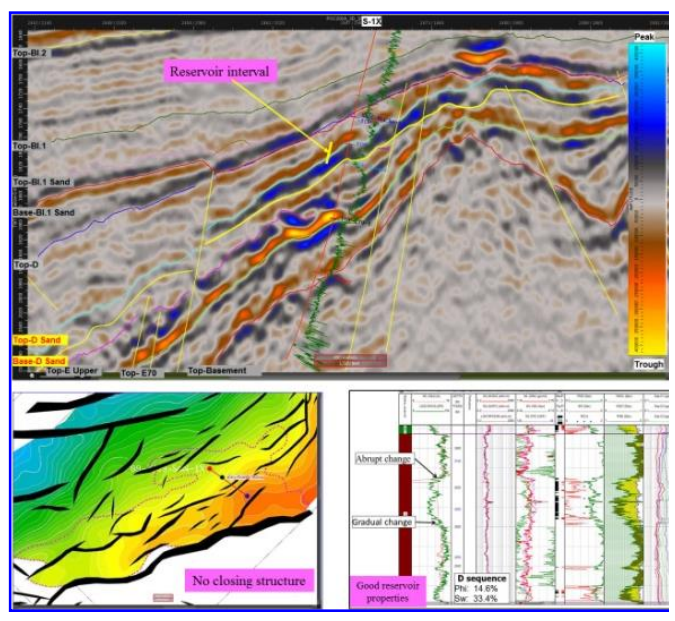

Figure 2. Stratigraphic trap confirmed by drilling results in Oligocene D with movable oil from imbibition test in well and no closing structure at top level

Petrophysical analyses allow the detailed interpretation of geologic sections and provide information on lithology, facies, reservoirs characteristics as well as sequence stratigraphy [7, 12]. Other supporting methods include petrographic analysis and paleo-biostratigraphy, 
playing important roles in interpretation of depositional environments.

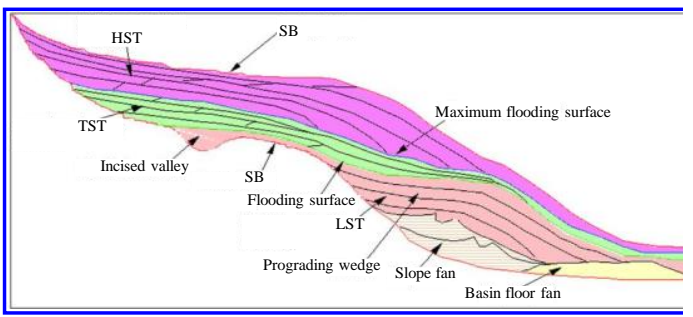

Figure 3. Seismic-based model for sequence and systems tract analysis. [4-7]. Distinctive stacking patterns and strata terminations are keys to differentiate system tracts on seismic sections

\section{$4 \quad$ RESULTS AND DISCUSSIONS}

Definition of stratigraphic section of the study area in this research is inherited from previous researches $[13,14]$ and is updated in accordance with available data as well as seismic data quality of the research area, including (from older sequence to younger sequence): E Lower, E upper, D, C, BI, BII, BIII and A. Within the scope of this study, third-order sequence Oligocene $\mathrm{D}$ and Oligocene $\mathrm{C}$ of Upper Oligocene are focused on to investigate the existence and distributions of stratigraphic traps.

\subsection{Results of seismic stratigraphy and seismic attributes analysis}

Seismic stratigraphy analysis starts with two seismic sections (red lines in) in combination with well $\operatorname{logs}$ analysis to define framework surfaces of sequence stratigraphy (such as Transgressive Surface, Maximum Flooding Surface and/or Sequence Boundaries) and to identify reflection patterns and architecture. Characteristics of seismic reflection (terminations, configurations..) are investigated on sections and extended throughout the study area for further analysis (Figure 12 and 13). Seismic attribute analysis is carried out on two 3D seismic cubes with correlation with well data to determine running windows for seismic attribute generations (Figure $6)$.

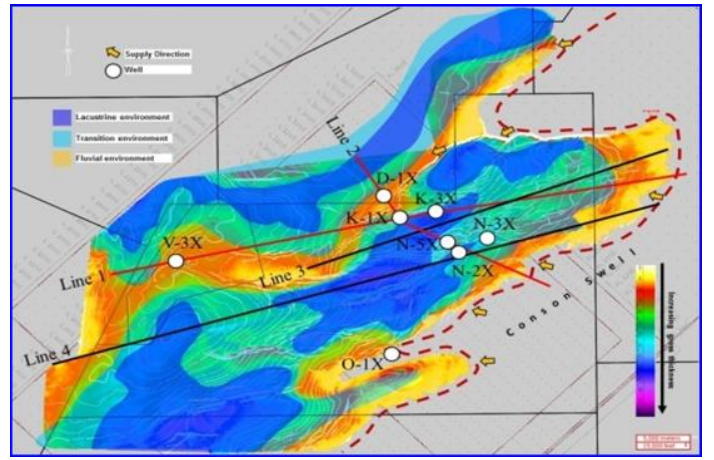

Figure 4. Location map showing location of seismic lines used for seismic stratigraphy

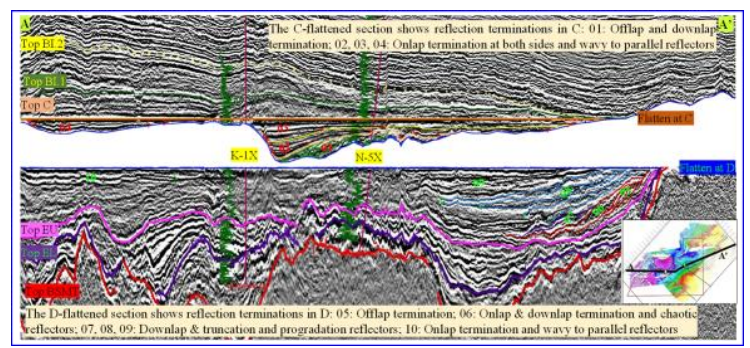

Figure 5. Seismic section flattened at $\mathrm{C}$ and $\mathrm{D}$ showing reflection terminations in these sequences

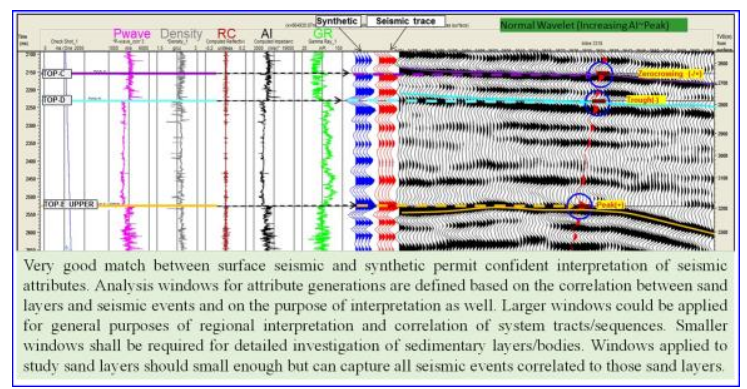

Figure 6. Synthetic seismogram of well K-1X showing good correlation between surface seismic and synthetic traces that is used for defining windows in seismic attribute analysis

Oligocene $C$ sequence: The upper boundary of this sequence is the top of Oligocene $\mathrm{C}$, and its base is the top of Oligocene D. These boundaries are identified by correlating well logs analysis and seismic stratigraphy analysis (Figure 5, 8 and 9).

Seismic characteristics of $\mathrm{C}$ sequence are strong amplitudes, moderate frequency, good to very good continuity, sub-parallel to parallel internal reflectors that onlapping towards basin's margin (Figure 5, 8 and 11). 


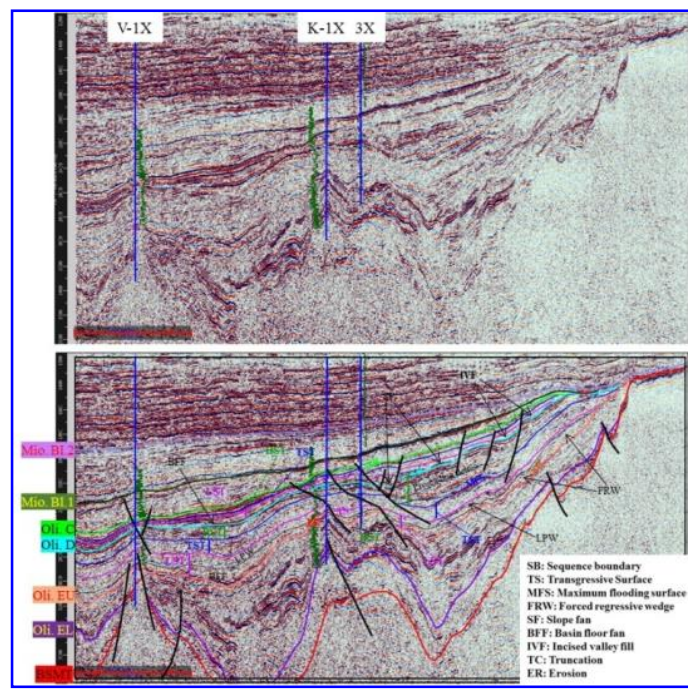

Figure 7. Sequence stratigraphic interpretation of seismic line 1 for Oligocene C and D. Picture B shows interpretation of seismic Line 1 with annotated stratigraphic surfaces

Petrographic analysis shows that Oligocene C sequence consists of sandstones interbedded with shale and small amount of siltstones that deposited in delta plain, delta front, prodelta to lacustrine environment [15]. Sandstones are majorly off white/white, fine to medium grained, sub-angular to sub-rounded, poorly to moderately sorted Arkose. Petrographic analysis show that the depositional environments of $\mathrm{C}$ sequence are fluvial, delta plain to lacustrine (Figure 9 and 10).

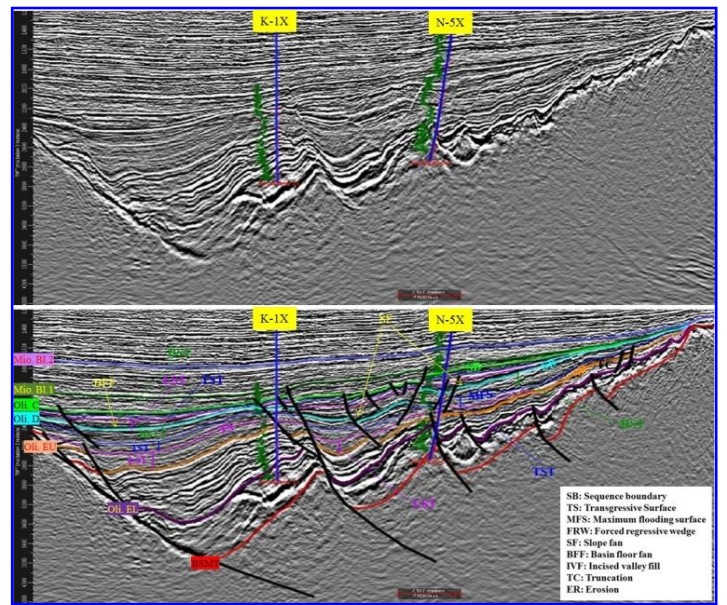

Figure 8. Sequence stratigraphic interpretation of seismic line 2 for Oligocene C and D. Picture B shows interpretation of seismic Line 1 with annotated stratigraphic surfaces

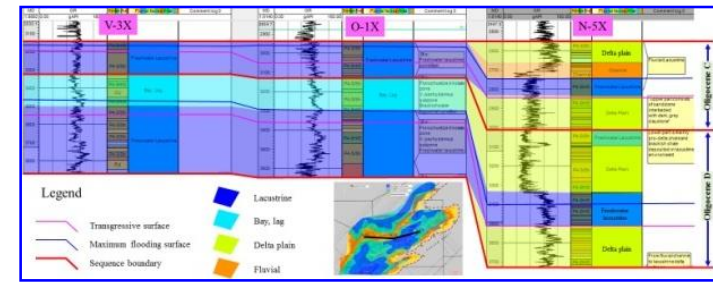

Figure 9. Well data correlation of V-3X, O-1X and N-5X for Oligocene $\mathrm{C}$ and $\mathrm{D}$

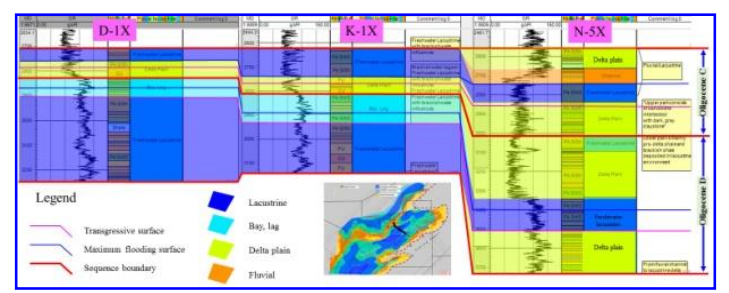

Figure 10. Well data correlation of D-1X, K-1X and N-5X for Oligocene $\mathrm{C}$ and $\mathrm{D}$

C sequence is divided into three system tracts including progradational lowstand system tract (LST) at the bottom, retrogradational transgressive system tracts (TST) in the middle and weakprogradational highstand system tract (HST) at the top (Figure 9, 10 and 11). The thickness of these system tracts do not vary much across the research area, showing that tectonic activities were less active during the deposition of $\mathrm{C}$ sequence in comparison with those in Oligocene D period.

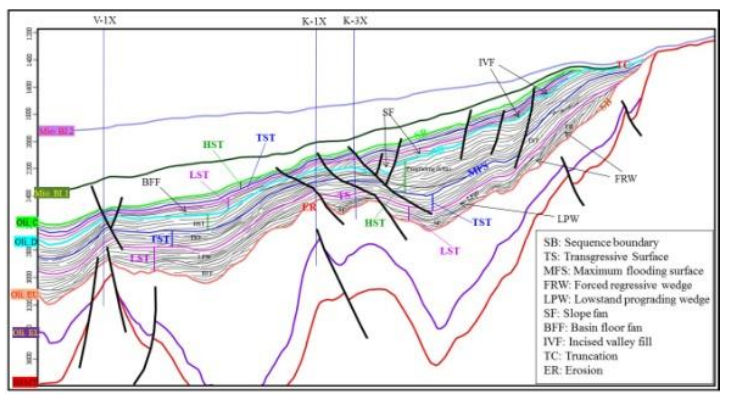

Figure 11. Seismic stratigraphic interpretation for Oligocene C and D. Fan deposits and prograding deltas were identified in lowstand system tracts and highstand system tracts respectively

Oligocene D: The upper boundary of this sequence is the top of Oligocene D. The lower boundaries are the top of pre-Tertiary basement at the proximity of Con Son swell or the top of Oligocene E. The top of Oligocene E was determined by the changes in stacking patterns of parasequences from aggradational/progradational stacking below to retrogradational stacking above 
(Figure 5 to 10).

Pertrographic analysis shows that D sequence consists of majorly shale interbedded with sandstones, siltstones and occasionally thin layers of coal. Sandstone is pale green, yellowish green, very fine, sub rounded, sub spherical, very well sorted, and well-cemented argillaceous matrix [15]. Toward Con Son swell at the area of $\mathrm{N}$ wells, the upper part of D sequence consists of majorly sandstones interbedded with dark, grey claystones that deposited in deltaic environments. Interpretation of well data indicate that the depositional environments of $\mathrm{D}$ sequence were majorly lacustrine to delta plain (Figure 9 and 10).

Oligocene D sequence is divided into three system tracts: lowstand system tract at the bottom, transgressive system tracts in the middle and highstand system tract at the top (Figure 5, 8 and 11). Seismic stratigraphic analysis shows the existence of fan deposits in lowstand system tract and prograding delta in highstand system tract (Figure 8). These deposits are considered important stratigraphic/combination traps in Oligocene D.

\subsection{Identification and prediction of traps' distribution}

Fan deposits in lowstand system tracts: lowstand system tracts of $\mathrm{C}$ and $\mathrm{D}$ sequences are divided into units of slope fan, basin floor fan and lowstand wedge (Figure 8). Basin floor fan and slope fan are consists of mostly coarse-grained sediments and are important targets of petroleum exploration. Seismic characteristics of these fans within the research area are oblique reflectors with downlap terminations onto the underlying older strata (Figures 12 and 13). These fans deposited near-source from the east and southeast in high energy settings (Figure 12). Taking the role of top seal for these lowstand fans are fine-grained deposits of corresponding transgressive system tracts that are assessed to have good seal capability (Figure 15). Therefore, these fans are potential targets for petroleum exploration. Traps of this type are predicted to distribute near basement highs or Con Son swell (Figure 14 and 17).

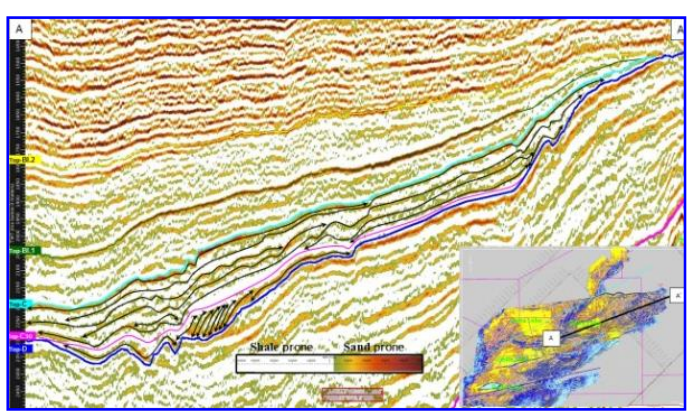

Figure 12. Seismic characteristics of lowstand fan in Oligocene $\mathrm{C}$

Deltaic deposits in highstand system tracts: Deltaic sandstone deposits of highstand system tracts are also considered potential stratigraphic traps in Upper Oligocene sequences in the research area (Figure 16). However, traps of this type have high risks regarding top seal capability because they were often overlaid by medium to coarse grained sediments of the following lowstand system tract deposited during the next water-level fall period (Figure 17). Traps of this type are predicted to distribute close to Con Son swell, near sediments' source that are favorable condition for the deposition of deltaic sandstones (Figure 14 and 17).

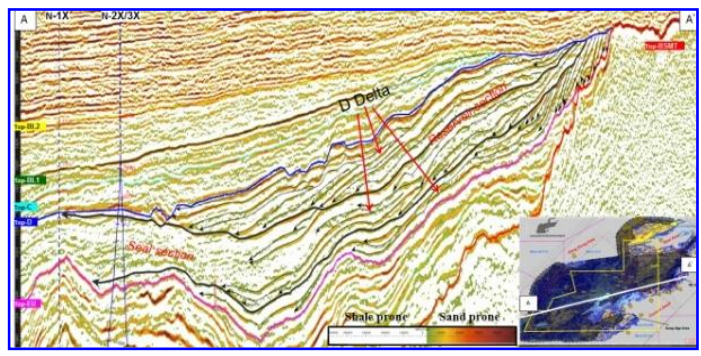

Figure 13. Seismic characteristics of lowstand fans and highstand deltas in Oligocene D

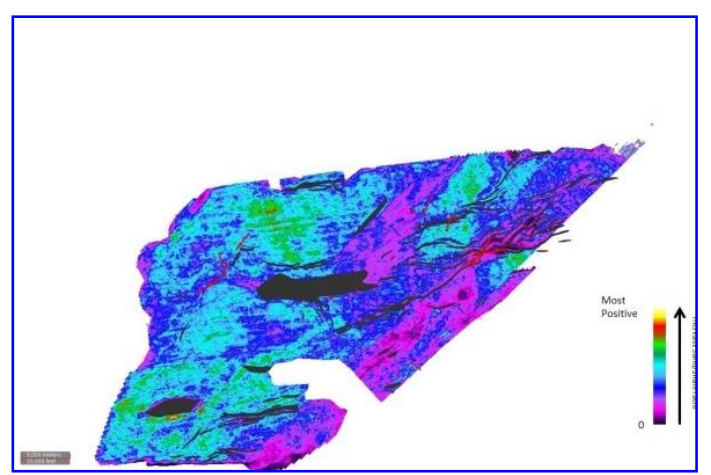

Figure 14. Sum of possitive amplitude map for LST of Oligocene $\mathrm{C}$ showing the posibility of fan-shaped stratigraphic traps 


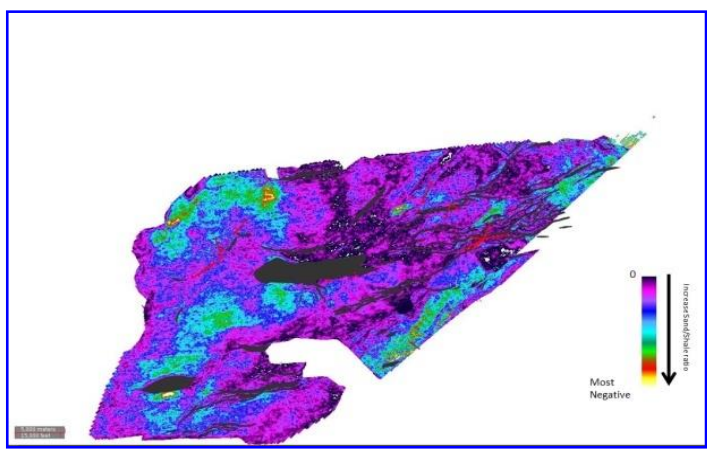

Figure 15. Sum of negative amplitude map along TS showing top seal capability for traps in LST of Oligocene C

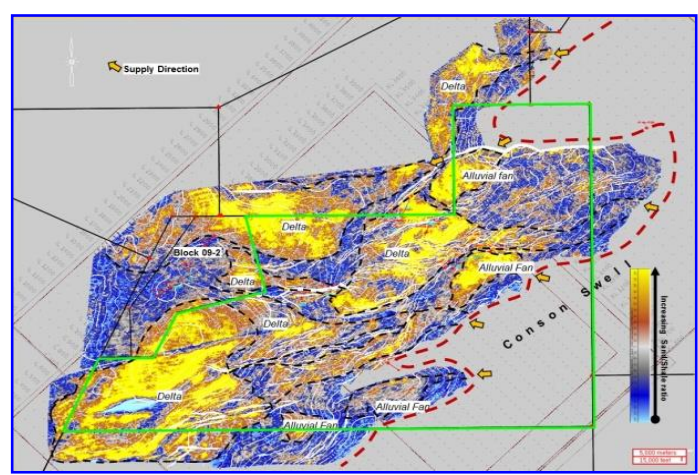

Figure 16. Prediction of distribution of stratigraphic traps in Oligocene C

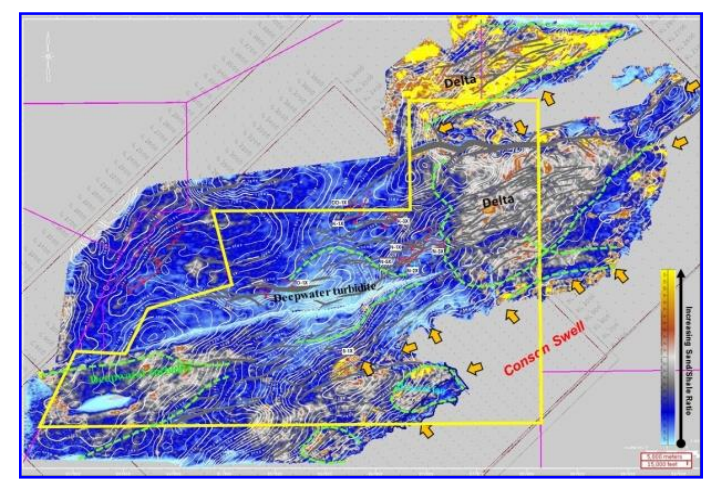

Figure 17. Prediction of distribution of stratigraphic traps in Oligocene D

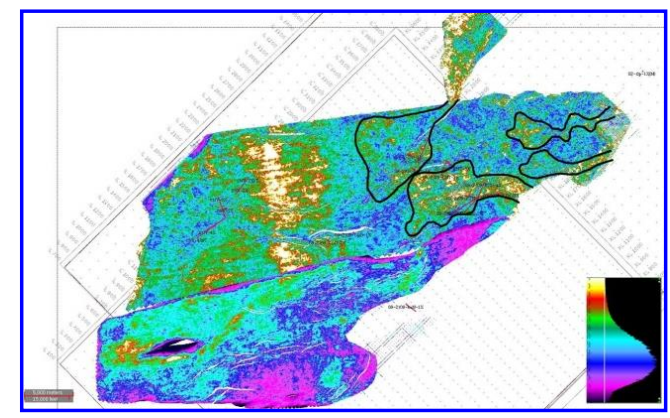

Figure 18. Maximum amplitude of HST in Oligocene C showing the posibility of deltaic fans as stratigraphic traps

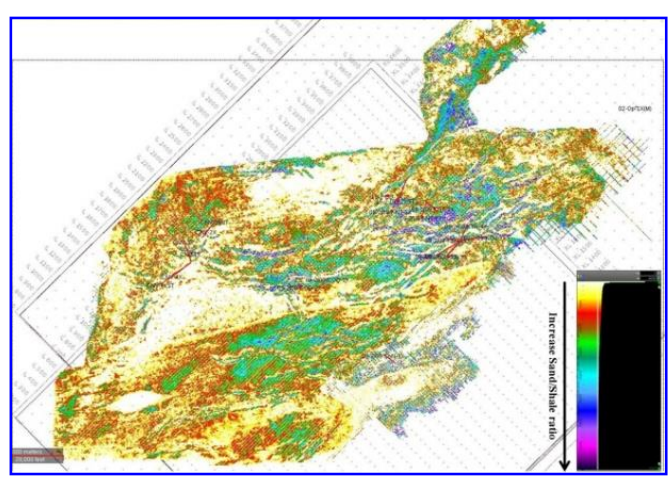

Figure 19. Maximum negative amplitude map along top of Oligocene $\mathrm{C}$ showing top seal capability for traps in HST of Oligocene C

\section{CONCLUSIONS}

Several statements can be concluded from the study results as following:

There exist stratigraphic traps in the form of deltaic fan deposits in Upper Oligocene sequences at the Southeastern margin of Cuu Long basin. They were formed during the water-level fall periods in lowstand system tracts with the source of sediments from the east-northeast, Con Son swell in particular. These traps distribute along the Western slope of Con Son swell. Top seals for these traps are the overlaying fine-grained sediments. Lateral seals are changes of facies from coarser grained sediments to contemporaneously deposited finer-grained sediments.

Sand bodies in prograding deltas during highstand system tracts could also be possible stratigraphic traps in Upper Oligocene sequences in the research area. However, petroleum exploration in these traps encounter higher risks 
regarding top seals and lateral seals due to the overlaying coarse grained sediments of the following lowstand system tract.

Further assessments on the hydrocarbon potential of these traps need to be carried out in order to plan proper strategies for exploration and appraisal of stratigraphic traps in the research area as well as the whole Cuu Long basin.

\section{REFERENCES}

[1] PVEP POC, 2014, Updated Appraisal Plan for Kinh Ngu Trang Nam Discovery, Reported to PVN and PVEP, 65 pp.

[2] Tran Le Dong and Phung Dac Hai, 2007, Cuu Long basin and hydrocarbon resources, in: The Petroleum Geology and Resources of Vietnam, The Science and Technology Publishing House, Vietnam, pp. 264-309.

[3] Hoan Vu JOC, 2007, Geological Evaluation Report for Retaining Final Area for $\mathrm{Ca} \mathrm{Ngu}$ Vang Field Development, Internal report to $\mathrm{PVN}$ và $\mathrm{PVEP}, 140-142$ pp.

[4] Mitchum R. M., Vail P. R. and Thompson S., 1977, Depositional sequence as a basic unit for stratigraphic analysis, in: Seismic stratigraphy - Application to hydrocarbon exploration, AAPG Memior 26, pp. 53-62.

[5] Mitchum R. M. and Vail P. R., 1977, Stratigraphic interpretation of seismic reflection patterns in depositional sequences, in: Seismic stratigraphy - Application to hydrocarbon exploration, AAPG Memior 26, pp. 117133.

[6] Emery D. and Myer K., 1996, Sequence stratigraphy, Blackwell Science, BP Exploration, Stockley Park, Uxbridge, London, pp. 45-60.

[7] Tan T. M., 2011, Seismic Prospecting, The Transport Publishing House, Vietnam, pp. 345-428.

[8] Chopra S. and Marfurt K., 2005, Seismic Attributes - A Historical Perspective: Attribute Review Paper $-75^{\text {th }}$ Ann of SEG.

[9] Chopra S. and Marfurt K., 2006, Seismic Attributes - a promising aid for geologic prediction, 2006 special edition, CSEG Recorded.

[10] Partyka G., James G., and John L., 1999, Interpretational applications of spectral decomposition in reservoir characterization, The Leading EDGE

[11] Taner M., 2001, Seismic Attributes, CSEG Recorder: Article, Rock Solid Images, Houston, USA.

[12] Rider, M., 1996, The Geological Interpretation of Well Logs, $2^{\text {nd }}$ Edition, Petroleum Exploration Consultant, Rider-French Consultant Ltd., Aberdeen and Sutherland, pp. 226-260.

[13] Nguyen Tien Long, 2004, Sequence stratigraphy of Kainozoi sedimentary section in the northern part of Cuu Long basin, $\mathrm{PhD}$ thesis, $157 \mathrm{pp}$.

[14] Tran Nghi, 2010, Sequence stratigraphy study in Song Hong, Сuи Long and Nam Con Son basins for evaluation of hydrocarbon and mineral resources, Final report to Ministry of Science and Technology, pp. 302-382.

[15] VPI, 2014, Reports of petrography and biostratigraphy analyses of wells in $N$ and $S$ areas, Internal reports to PVEP POC.
Nguyen Dinh Chuc received B.S. degree in Petroleum Geology from Ha Noi University of Mining and Geology, Ha Noi, Vietnam in 1999 and M.S. degree in Applied Geophysics from Chiang Mai University, Chiang Mai, Thailand in 2005. He is currently pursuing Ph.D. degree in Petroleum Engineering at Ho Chi Minh City University of Technology - VNU-HCM, Vietnam.

From 2002 to 2007, he worked for PetroVietnam Exploration Production Company as Geophysicist in charged for seismic interpretation supporting for hydrocarbon potential evaluation of blocks in Cuu Long basin. Working as Senior Geophysicist/Team Leader in Exploration Division of PetroVietnam Exploration Production Corporation from 2007 to 2010, he was in charged for QC of seismic interpretation applied in exploration and reservoir geophysics. From 2010 to present, he has been assigned as Deputy Exploration Manager of PVEP POC in charging for exploration activities in block 09-2/09, Cuu Long basin, offshore Vietnam.

Mr. Chuc has over 15-year experience of seismic interpretation, including structural, stratigraphic and reservoir geophysics. $\mathrm{He}$ is also experienced in basin analysis, structural and play geology, sequence stratigraphy and sedimentary depositional environment interpretation. $\mathrm{He}$ has been a member of SPE, SEG for years.

Nguyen Van Tu received B.S. degree in Geology Engineering from PetroVietnam University in 2016 and is currently pursuing the M.S. degree in Production and Logistics at Politecnico Di Torino, Turin, Italy.

From May 2016 to Jan 2017, he worked as an Operating Assistant at Global PetroWell Services, Vung Tau, Vietnam, in charged for assisting professional well intervention Senior Operators. From January to October 2017, he worked as Geophysicist for PVEP POC in Ho Chi Minh City involving seismic interpretation and sedimentary depositional environment analysis. Currently, he is attending Master Program majoring in Production and Logistics organized and funded by Eni with the co-organizer Politecnico Di Torino University, Italia.

$\mathrm{Mr}$. Tu has been a SPE member for 3 year since 2014, he was also awarded with second-runners in the 2015 Petrobowl contest held by SPE Vietnam Section.

Nguyen Quang Hung was born in $\mathrm{Ha}$ Noi, Vietnam in 1990. He received the B.S. degree in general geophysics from University of Oklahoma, Norman, OK, USA in 2013. 
From 2014 to present, he has been working as a Geophysicist at PetroVietnam Domestic Exploration Production Operating Company Limited.

Mr. Hung's professions consist of 2D/3D seismic interpretation, seismic attributes, and seismic sequence stratigraphy.

Bui Van Cuong received the B.S. degree in Geophysics from Ha Noi University of Mining and Geology, Hanoi, Vietnam in 2004.

From 2006 to 2009, he worked for PTSC Marine as a Geophysicist with major interests of operating and monitoring 2D marine seismic data acquisition. From 2009 to present, he has been working for PetroVietnam Exploration and Production Corporation (PVEP) as Senior Geophysicist who is in charged for structural and stratigraphic interpretation of $2 \mathrm{D}$ and $3 \mathrm{D}$ seismic data supporting for oil and gas exploration activities.

Truong Quoc Thanh received the B.C. degree in Petroleum Geology Engineering from Ho Chi Minh City University of Technology - VNUHCM, Vietnam, in 2013 and the M.S. degree in Petroleum Engineering from Ho Chi Minh City
University of Technology - VNU-HCM, Vietnam, in 2015.

From 2014 to present, he was a Researcher at Petroleum Geology Department, Faculty of Geology and Petroleum Engineering, Ho Chi Minh City University of Technology - VNU-HCM, Vietnam.

Mr. Thanh's research interest includes geophysics, reservoir engineering.

Tran Van Xuan received the B.C. degree in Geological Engineering from Ho Chi Minh City University of Technology - VNU-HCM, Vietnam in 1984 and Ph.D. degree in Geology from Ha Noi University of Mining and Geology, Ha Noi, Vietnam in 2004.

From 1984 to present, he is a Lecturer, Head of Petroleum Geology Department, Faculty of Geology and Petroleum Engineering, Ho Chi Minh City University of Technology - VNU-HCM, Vietnam.

Asst. Prof. Xuan's research interest includes applied petroleum engineering, reservoir engineering, exploration unconventional, water supply technology, waste technology, geotechnical, hydrogeology. 


\title{
Úng dụng phân tích địa tầng địa chấn đánh giá bẫy địa tầng trong trầm tích Oligoxen thượng vùng Đông Nam, Bể Cửu Long
}

\author{
Nguyễn Đình Chức, Nguyễn Văn Tú, Nguyễn Quang Hưng \\ Bùi Văn Cương, Trương Quốc Thanh, Trần Văn Xuân
}

Tóm tắt-Sau nhiều thập kỷ khai thác, trũ̃ lượng dầu khí trong thân dầu truyền thống móng nứt nẻ trước Đệ Tam và bẫy cấu trúc tuổi Kainozoi ngày càng cạn kiệt, các trữ lượng còn lại trong các bẫy dạng này không đáp ứng được yêu cầu của phát triển và khai thác, các hoạt động tìm kiếm thăm dò trong bể Cửu Long cần hướng đến các dạng bẫy địa tầng và bẫy hỗn hợp. Kết quả nghiên cứu vùng rìa Đông Nam bể Cửu Long cho thấy các dấu hiệu tiềm năng dầu khí của bẫy vát nhọn địa tầng. Tuy nhiên việc xác định đặc trưng phân bố cũng như đánh giá tiềm năng dầu khí của các đối tượng này ẩn chứa nhiều trở ngại nên rất cần áp dụng tổ hợp nghiên cứu địa chấn địa tầng với thuộc tính địa chấn và tài liệu địa vật lý giếng khoan.

Kết quả tổ hợp nghiên cứu tài liệu địa chấn, địa vật lý giếng khoan cho thấy bẫy địa tầng/hỗn hợp trong tập $\mathrm{C}$ và $\mathrm{D}$ tuổi Oligoxen muộn được hình thành trong hệ tướng biển thấp có dạng sigma-xiên chéo phát triển gá đáy xuống thành hệ phía dưới, hình thành trong môi trường cửa sông, tam giác châu. Việc tích hợp nghiên cứu thuộc tính địa chấn và số liệu địa vật lý giếng khoan cũng cho phép xác định phân bố dạng quạt của các bẫy dạng này.

Trong giai đoạn kế tiếp cần tiến hành các nghiên cứu bổ sung nhằm đánh giá toàn diện tiềm năng dầu khí của dạng bẫy này cũng như giảm thiểu rủi ro trong công tác tìm kiếm thăm dò.

Tù khoá-Bẫy địa tầng, bẫy hỗn hợp, biến đổi tướng, hệ tướng biển thấp, địa tầng địa chấn. 